\title{
RAPD primer screening for markers development of Jinten Hitam (Nigella sativa L.) authentication
}

\author{
Dyah Subositi ${ }^{1 *}$, Joice ${ }^{2}$, Exyupransia Mursyanti ${ }^{2}$, Harto Widodo $^{1}$, and Yuli Widiyastuti ${ }^{1}$ \\ ${ }^{1}$ Medicinal Plant and Traditional Medicine Research and Development Center, NIHRD-Ministry of \\ Health, Tawangmangu, Central Java, Indonesia \\ ${ }^{2}$ Faculty of Technobiology, Atma Jaya University, Yogyakarta, Indonesia
}

\begin{abstract}
Jinten hitam (Nigella sativa) is one of the medicinal plants in the family Ranunculaceae, native to the Mediterranean region and several regions of Asia. The seed of Nigella sativa is widely cultivated, distributed, and used in pharmaceuticals, cosmetics, and food industries. Due to similar seed morphology to its potential adulterant such as Corchorus spp., $N$. sativa seeds are susceptible to adulteration and substitution in markets. Molecular markers have become one of the most reliable methods for the identification and authentication of medicinal plants. The objective of this study was to select the random amplified polymorphic DNA (RAPD) primer for generating authentication methods of Jinten hitam ( $N$. sativa). Genomic DNA was extracted from samples of $N$. sativa seed, Corchorus sp. seed, and a mixture of both samples. Forty-two random RAPD primers were used in this study. A total of 227 DNA fragments were produced from 37 amplified RAPD primers, out of which $65 \%$ were polymorphic. Primer OPK-4 and OPC-12 generated specific fragments in N. sativa, meanwhile, Primer OPB-1, OPL-5, OPM-3, OPD-5, and OPC-12 generated specific fragments for Corchorus. RAPD molecular marker was able to authentication Jinten hitam (N. sativa) and Corchorus sp. using a selected primer. This research was the first report on RAPD primer screening for Nigella sativa authentication from its potential adulterant (Corchorus spp.).
\end{abstract}

\section{Introduction}

Nigella sativa L. is a medicinal plant member of the family Ranunculaceae. This plant's cultivation and distribution are mainly in the Mediterranean countries, southern Europe, North Africa, south and southwest Asia [1]. Chemical contains $N$. sativa seeds include: fixed oil (32-40\% of unsaturated fatty acids), proteins, alkaloids such as nigellicimine, nigellicimine n-oxide, nigellidine and nigellicine, saponins, and volatile oils $(0.4-0.45 \%$ contains saturated fatty acids, which include nigellone, thymoquinone, thymohydroquinone) [2]. Seeds of Nigella sativa have been used in the food industry and treat many diseases involved in respiration, the system of the gastrointestinal, immune

* Corresponding author: dyah.subositi@gmail.com 
system, and nervous systems [3]. Nigella sativa in Indonesia is well known as jinten hitam and scientifically proven as "jamu saintifik" used to treat dyspepsia or indigestion [4].

Seeds of N. sativa are black colored, ovoid, trigonous, angular, with a length of 2.5-3.5 $\mathrm{mm}$ and 1.5-2 mm wide, slightly smell aromatic, and taste bitter [5,6]. In the traditional Indonesian market, $N$. sativa seeds are frequently adulterated with Corchorus sp. seeds or "Jinten hitam lokal". Seeds of "jinten hitam lokal" are greyish-black colored, rhomboidal, angular, with the length $1.5-2.5 \mathrm{~mm}$, odorless. The genus Corchorus contains about 100 species and primarily distributed in tropical and subtropical regions. Generally, this genus is cultivated as a source of fiber and vegetables [7].

According to guidelines of research and evaluation methodologies on traditional medicine from WHO, the first and essentials step is to verify or identify the correct raw materials to ensure their quality, safety, and efficacy [8]. Authentication is a challenge in medicinal plants; ideally, this process start from harvesting to the final product. Plant raw material for the traditional medicine industry obtain from untrained collectors and generally comes from rural areas. This process has the potential to cause the quality of raw materials to be less and the potential for adulteration or substitution [9]. Adulteration of the medicinal plant may be both unintentional and intentional. Unintentional adulteration occurs due to various reasons: confusion in vernacular names, lack of knowledge related to the authentic source, share the similarity in morphology and color, lack of natural plant or sample, lax collections [10].

Several techniques have been developed to identify or authenticate marketed herbs, morphology, anatomy, chemical fingerprints, and DNA-based approaches. Some of these techniques have advantages and disadvantages [11]. The identification of raw materials for traditional medicine is usually through organoleptic, microscopic characters (size, shape, color, smell, taste, texture) [12]. This technique is easy but has limitations due to subjective depending on expertise and experience, especially on different materials in related species. Moreover, the species and its adulterants share a similar character. The use of chemical analysis has several limitations because the outputs are influenced by plant age, physiology, and storage conditions after harvesting. Besides, related plant species contain similar chemical components, so it is difficult to identify [12].

Molecular markers have several advantages over phenotypic characters; among others, this technique is not influenced by an internal factor such as physiological conditions and external factors like environmental factors [13]. Random Amplification of Polymorphic DNA (RAPD) molecular markers have been used to authenticate medicinal plants due to small samples for analysis and do not require specific tissue/samples [14]. This study's objective was to screen RAPD primer for Jinten hitam (Nigella sativa) authentication from its potential adulterant (Corchorus sp.).

\section{Material and method}

\subsection{Plant materials}

Samples of N. sativa seed and its potential adulterant (Corchorus sp.) were collected from voucher specimens in the medicinal plant post-harvest laboratory of B2P2TOOT (Figure 1). The samples were identified in the laboratory of medicinal plant systematics B2P2TOOT.

\subsection{Genomic DNA extraction}

Samples of this research were N. sativa seed, Corchorus sp. seed, the mixture of N. sativa dan Corchorus (1:1), a mixture of $N$. sativa dan Corchorus (1:3), a mix of $N$. sativa dan 
Corchorus (3:1). The total genomic DNA was extracted from 0.15 gr of seed sample performed by DNA kit isolation method with minor modification (Thermo Scientific gene jet plant genomic DNA purification Mini Kit, Catalogue number K0791). Then, isolated genomic DNA from samples was determined of their concentration and purity using UVVis spectrophotometer with absorbance at 260/280 nm. Evaluation of the quality of genomic DNA by running in $1 \%$ agarose gel of electrophoresis.
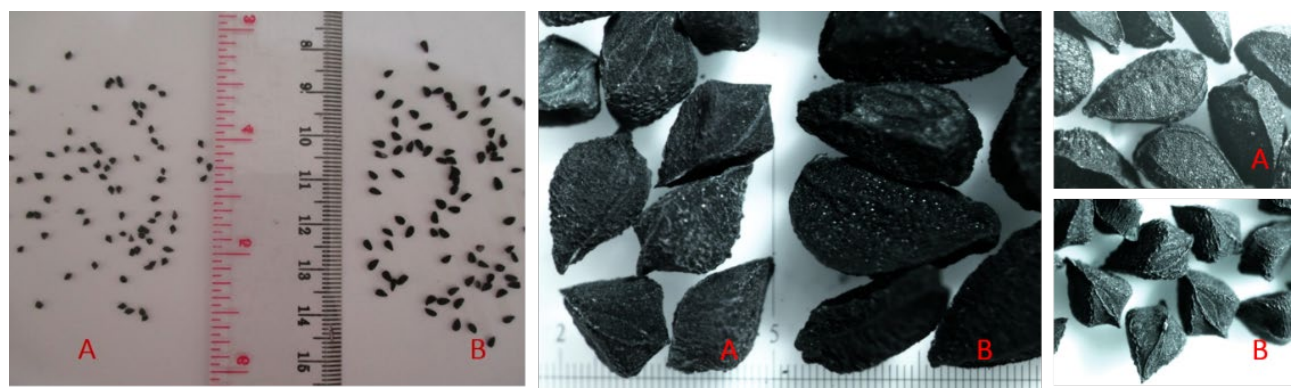

Fig. 1. Jintan hitam (Nigella sativa) seeds and its potential adulterant (Corchorus sp.). A. Corchorus sp.; B. Nigella sativa.

\subsection{PCR-RAPD analysis}

We used a random of 42 RAPD primers in this study (Table 1). The PCR reaction mixture $(25.2 \mu \mathrm{L})$ containing DNA template two $\mu \mathrm{L}$, PCR mix $12.6 \mu \mathrm{L}$, primer $0.8 \mu \mathrm{L}$, dan nuclease-free water 9.6 $\mu \mathrm{L}$. PCR amplifications were carried out using a thermal cycler $(\mathrm{C}$ 1000 Bio-Rad, USA) with the following conditions: $95^{\circ} \mathrm{C}$ for $3 \mathrm{~min}$, (pre-denaturation) followed by 39 cycles of $94^{\circ} \mathrm{C}$ for $1 \mathrm{~min}$, annealing at $36^{\circ} \mathrm{C}$ for $60 \mathrm{~s}$, and elongation at $72^{\circ} \mathrm{C}$ for $2 \mathrm{~min}$, and a final extension at $72^{\circ} \mathrm{C}$ for $7 \mathrm{~min}$. Furthermore the PCR-RAPD fragments were separated by $1,8 \%$ agarose gels, $60-80 \mathrm{~V}$ for 90 minutes. Visualization of electrophoresis gel using UV light was observed and photographed using a gel documentation system (Imaging System XR + of Bio-Rad, USA).

\subsection{Data analysis}

Qualitative analysis was used in this study. Amplified DNA fragments were selected based on DNA fragment thickness and polymorphism from each primer used to amplified samples. The selection of potential DNA fragments for authentication was clear, and thick DNA fragments that specific $N$. sativa or Corchorus sample found in the mixture of both samples.

\section{Results and discussion}

Correct identification of medicinal plant species raw material is the first and essential step to ensure herbal products of quality, efficacy, and safety. Although $N$. sativa has been widely used for various purposes in Indonesia, its cultivation and production have not been reported or minimal information. Most of $N$. sativa in Indonesia are imported from its producing country. It may lead to and potential for $N$. sativa adulteration.

The RAPD marker for authentication is one of the molecular markers with several advantages over morphological characterization and chemical profiling. Potential specific fragments in species could be obtained from RAPD molecular markers, and they allow for species identification and characterization without requiring prior knowledge of the DNA sequence [11]. Genomic DNA extraction is the first step in molecular authentication. In this 
regard, a total genomic DNA was successfully extracted from all samples in a good quality shown by the purity value 1,65-1,71, and the concentration ranged between 54 to 126 $\mathrm{ng} / \mu \mathrm{L}$ (Figure 2). Poyras [15] reported that the total genomic extracted from $N$. sativa with a purity range of 1.70-1.72 and concentration ranging from $14-20 \mathrm{ng} / \mu \mathrm{l}$ was sufficient for RAPD analysis.

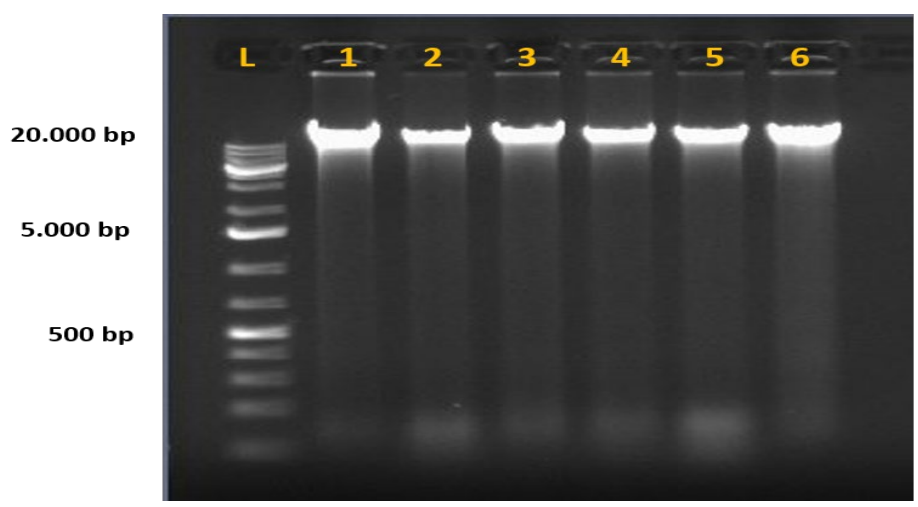

Fig. 2. Genomic DNA of Jintan hitam (Nigella sativa) and its potential adulterant (Corchorus sp.). [1] Nigella sativa; [2] Corchorus sp.; [3,4] the mixture of Nigella sativa: Corchorus sp. (1:1); [5] the mixture of Nigella sativa: Corchorus sp. (1:3); [6] the mixture of Nigella sativa: Corchorus sp. (3:1); $\mathrm{L}=$ ladder one $\mathrm{k}$ bp.

Out of 42 RAPD primers screened, five primers of them showed not able to generate DNA fragments. A total of 227 DNA fragment were produced from 37 primers with a polymorphism percentage of $90.3 \%$; fragments size ranged from 230 to $4.420 \mathrm{bp}$ (Table 1). RAPD primers mainly generated specific or unique fragments in both species. Primers OPB-1, OPC-12, OPD-5, OPK-4, OPL-5, and OPM-3 clearly distinguished N. sativa and Corchorus sp. by reasons of the presence and absence of unique fragments. Specific and unique DNA fragments generated from each primer of $N$. sativa and Corchorus sp. had potential authentication usage (Figure 3). 
Table 1. DNA fragments of Nigella sativa and Corchorus sp. generated using 42 RAPD primers

\begin{tabular}{|c|c|c|c|c|c|c|c|}
\hline \multirow{3}{*}{$\begin{array}{l}\text { RAPD } \\
\text { Primer }\end{array}$} & \multirow{3}{*}{$\begin{array}{c}\text { Total } \\
\text { Fragments }\end{array}$} & \multirow{3}{*}{$\begin{array}{l}\text { Monomor-phic } \\
\text { fragments }\end{array}$} & \multirow{3}{*}{$\begin{array}{c}\text { Polymor- } \\
\text { phism } \\
(\%)\end{array}$} & \multicolumn{4}{|c|}{ DNA Fragments } \\
\hline & & & & \multicolumn{2}{|c|}{ Nigella sativa } & \multicolumn{2}{|c|}{ Corchorus sp. } \\
\hline & & & & Strong & Weak & Strong & $\begin{array}{l}\text { We } \\
\text { ak }\end{array}$ \\
\hline OPK-4 & 8 & - & 100 & 1 & 2 & - & 3 \\
\hline OPB-1 & 5 & - & 100 & - & 2 & 1 & - \\
\hline OPL-5 & 14 & 3 & 78.6 & - & 4 & 1 & 2 \\
\hline OPM-3 & 4 & - & 100 & - & 2 & 1 & 1 \\
\hline OPA-19 & 6 & - & 100 & - & 2 & - & 1 \\
\hline OPD-5 & 7 & 1 & 85.7 & - & 2 & 1 & 1 \\
\hline OPC-12 & 7 & - & 100 & 1 & 3 & 1 & 2 \\
\hline OPB-2 & 3 & 1 & 66.7 & 1 & - & - & - \\
\hline OPA-10 & 5 & - & 100 & - & 3 & 1 & - \\
\hline OPH-13 & 8 & - & 100 & - & 3 & 1 & 2 \\
\hline OPA-17 & 6 & 1 & 83.3 & - & 2 & - & 1 \\
\hline OPA-18 & 8 & 2 & 75 & - & 5 & - & 1 \\
\hline OPA-2 & 9 & 1 & 88.9 & - & 4 & - & 2 \\
\hline OPA-3 & 7 & 1 & 85.7 & 1 & - & - & 2 \\
\hline OPB-3 & 3 & - & 100 & - & 1 & 1 & - \\
\hline OPB-4 & 5 & 1 & 80 & - & 2 & 1 & - \\
\hline OPR-7 & 6 & - & 100 & - & 1 & - & 2 \\
\hline OPL-4 & 4 & 1 & 75 & - & - & - & 2 \\
\hline OPM-4 & 7 & - & 100 & - & 3 & 1 & 1 \\
\hline OPA-5 & 7 & - & 100 & - & 4 & 1 & 1 \\
\hline OPA-6 & 3 & - & 100 & - & 3 & - & - \\
\hline OPM-1 & 6 & 1 & 83 & - & - & - & 2 \\
\hline OPA-4 & 5 & - & 100 & 1 & 1 & 2 & 1 \\
\hline OPW-6 & 7 & 1 & 85.7 & - & - & - & - \\
\hline OPW-8 & 7 & - & 100 & - & 2 & 1 & - \\
\hline OPH-20 & 8 & - & 100 & 1 & 1 & 1 & - \\
\hline OPA-1 & 5 & - & 100 & 1 & - & - & - \\
\hline OPL-1 & 6 & - & 100 & - & 3 & 1 & - \\
\hline OPL-2 & 7 & - & 100 & - & - & - & 1 \\
\hline OPL-3 & 4 & 2 & 50 & - & 1 & 1 & 1 \\
\hline OPM-2 & 11 & - & 100 & - & 1 & - & - \\
\hline OPM-5 & 4 & 1 & 75 & - & 2 & - & 1 \\
\hline OPJ-6 & 5 & 1 & 80 & - & 2 & - & - \\
\hline OPK-1 & 4 & 1 & 75 & - & 2 & - & - \\
\hline OPK-3 & 5 & 2 & 60 & - & - & - & 1 \\
\hline OPJ-1 & 5 & - & 100 & 1 & 1 & - & 1 \\
\hline OPJ-4 & 6 & 1 & 83 & - & - & - & 1 \\
\hline OPJ-2 & - & - & - & - & - & - & - \\
\hline OPJ-3 & - & - & - & - & - & - & - \\
\hline OPG-1 & - & - & - & - & - & - & - \\
\hline OPK-5 & - & - & - & - & - & - & - \\
\hline OPA-16 & - & - & - & - & - & - & - \\
\hline Total & 227 & 22 & - & 8 & 64 & 17 & 33 \\
\hline Average & 6.13 & 0.60 & 90.3 & - & - & - & - \\
\hline
\end{tabular}

Strong : Thick and clear DNA fragment also appear in the mixture sample

Weak : Thin and smear DNA fragment do not appear in the mixture sample

DNA fragments as a candidate for authentication should have appeared in the sample mixture. Adulteration may not fully or partially substitute the genuine with the adulterants 
(Figure 3). Herbal adulteration is the deliberate practice of replacing original material, either part or entire, with other materials with quality, chemical content, therapeutic properties that are similar to, lower than, or completely different from that the original material for increasing profit gain [10]. Therefore, developed markers should detect the genuine material and do not substitute partially or fully with other substances.

The results showed primer OPC-12 generating the specific and unique fragments for $N$. sativa and Corchorus sp. (Table 2). Selection of those DNA fragments due to the following criteria: clear and thick DNA fragments specific in N. sativa and Corchorus sp. sample, which is also found in the mixture of both samples. Molecular marker techniques based on the number of polymorphisms detected in each accession or species and unique/specific DNA fragments can distinguish from their contaminants [16]. Specific DNA fragments also produce from selected RAPD primers, namely OPC-1, OPC-4, OPC-6, OPC-7, and OPC-8 discriminated $P$. nigrum and $C$. papaya based on the presence and absence of unique bands [17]. Species specifics fragments of Curcuma longa and C. zedoaria were produced by using RAPD primers OPA-2, OPA-4, OPA-7, and OPC-5; the DNA fragments could clearly distinguish those species [18].

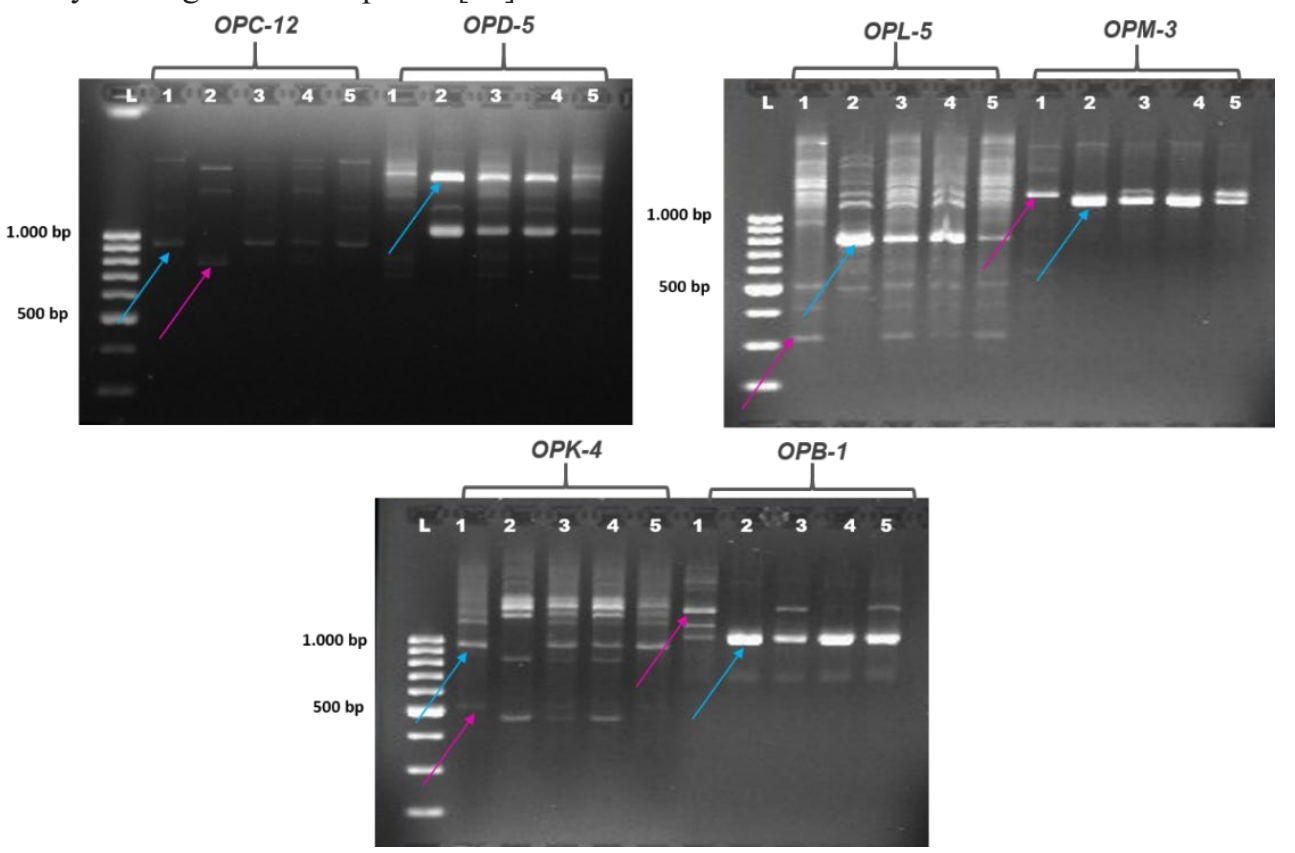

Fig. 3. RAPD analysis carried out using primer OPC-12, OPD-5, OPL-5, OPM-3, OPK-4, and OPB1. [1] Nigella sativa; [2] Corchorus sp.; [3,4] mixture of Nigella sativa: Corchorus sp. (1:1); [5] mixture of Nigella sativa: Corchorus sp. (1:3); L= DNA ladder 100 bp; blue arrow = strong DNA fragment, pink arrow $=$ weak DNA fragment.

In some research, the RAPD techniques mainly were used to assess genetic variation among the accession of $N$. sativa. Germplasm identification and fingerprinting of 32 those accessions from Pakistan were carried out using 15 selected RAPD primers [19]. The genetic diversity of $35 \mathrm{~N}$. sativa genotypes from Pakistan were successfully assessed using four RAPD markers [20]. Meanwhile, 10 RAPD primers effectively evaluated variation in 18 Iranian populations of this species [21]. The high genetic variations and polymorphisms among 16 accessions of $N$. sativa from various Iran regions were revealed using nine selected RAPD primers [22]. Nigella sativa from multiple geographies and major producers, such as India, Pakistan, Saudi Arabia, Egypt, Oman, Syria, Tunisia, and Turkey, were successfully investigated for genetic diversity using 8 RAPD primers [23]. Eleven 
RAPD primers successfully assessed the genetic diversity of $12 \mathrm{~N}$. sativa accessions from Afghanistan and India [24].

Table 2. Specific DNA fragments for Nigella sativa authentication

\begin{tabular}{|l|c|c|c|c|c|c|}
\hline \multirow{2}{*}{ Species } & \multicolumn{5}{|c|}{ Primer/ Size of specific DNA fragments (bp) } \\
\cline { 2 - 7 } & OPB-1 & OPC-12 & OPD-5 & OPK-4 & OPL-5 & OPM-3 \\
\hline Nigela sativa & - & 970 & - & 940 & - & - \\
\hline Corchorus sp. & 985 & 790 & 1.725 & - & 820 & 1.270 \\
\hline Total Fragments & 1 & 2 & 1 & 1 & 1 & 1 \\
\hline
\end{tabular}

Traditional methods for authentication of herbal materials have several limitations, i.e., personal skills and experience, time-consuming, difficulties in identifying of samples in dried and powder conditions [25]. The correct identity of $N$. sativa is essential to ensure its proper use; therefore, it is necessary to develop effective, efficient, and reliable methods as a tool for authentication and quality control. Authentication of herbal material using RAPD was employed in several commercially medicinal plants such as Tribulus terrestris vs. Pedalium murex, Eclipta alba that often adulterated with Wedelia calendulacea [26], Turmeric (Curcuma sp.) [18], Piper nigrum [17]. Adulteration of N. sativa mainly occurs for commercial reasons. This is influenced by the same nomenclature or vernacular names, also morphologically similar but biologically different seeds [25]. Rather and Jain [27] reported adulteration of Nigella sativa in India. The seeds were adulterated and substituted by non-viable and aged Allium cepa seeds [27].

\section{Conclusions}

The results may be used for further research, especially to evaluate and identify jinten hitam (N. sativa) seed in local markets using selected RAPD primers by following the reaction method. Furthermore, further research will be carried out on the development marker of sequence characterized amplified regions (SCAR) in Nigella sativa. Authentication and evaluation using complete characters can provide complete information on medicinal plants. In herbal authentication, one method should be combined with other ways to reveal maximum results.

Acknowledgments. The authors acknowledge the financial support and laboratory permits by the Head of B2P2TOOT Tawangmangu towards this research.

\section{References}

1. S. K. T. Venkatachallam, H. Pattekhan, S. Divakar, U. S. Kadimi, J. Food Sci. Technol. 47, 598 (2010)

2. F. Forouzanfar, B. S. Fazly Bazzaz, H. Hosseinzadeh, Iran. J. Basic Med. Sci. 17, 929 (2014)

3. Z. Gholamnezhad, R. Keyhanmanesh, M. H. Boskabady, J. Funct. Foods. 17, 910 (2015)

4. A. Triyono, Tujuh ramuan jamu saintifik pemanfaatan mandiri oleh masyarakat (Badan Litbang Kesehatan, Kementerian Kesehatan RI, Jakarta, 2016)

5. S. Sultana, H. M. Asif, N. Akhtar, A. Iqbal, H. Nazar, R. U. Rehman, J. Pharmacogn. Phytochem. 4, 103 (2015)

6. K. E.-D. Hussein El-Tahir, D. M. Bakeet, J. Taibah Univ. Med. Sci. 1, 1 (2006)

7. N. M. Fawzi, Middle East J. Agric. Res. 07, 1 (2018) 
8. World Health Organization, General guidelines for methodologies on research and evaluation of traditional medicine (World Health Organization, Geneva, 2000)

9. S. Khan, K. J. Mirza, M. Z. Abdin, EurAsian J. Biosci. 1 (2010)

10. O. Prakash, J. Med. Plants Stud. 1, 127 (2017)

11. Y. M. Lee, Y. Ji, Y. M. Kang, W. J. Kim, G. Choi, B. C. Moon, Int. J. Clin. Exp. Med. 9, $40(2015)$

12. S. H. Ganie, P. S. Srivastava, A. Narula, Z. Ali, M. P. Sharma, EurAsian J. Biosci. 39 (2012)

13. Z. Mei, X. Zhang, M. A. Khan, S. Imani, X. Liu, H. Zou, C. Wei, and J. Fu, Electron. J. Biotechnol. 30, 6 (2017)

14. M. Sarwat, S. Srivastava, and T. H. Khan, Int. J. Pharmacogn. Phytochem. Res. 8, 1417 (2016)

15. I. Poyraz, Bilecik Şeyh Edebali Üniversitesi Fen Bilim. Derg. 1, 22 (2014)

16. M. Hamouda, J. Genet. Eng. Biotechnol. 17, 1 (2019)

17. S. Khan, K. Jabeen Mirza, F. Anwar, M. Zainul Abdin, Environ. We an Int. J. Sci. Technol. 5, 47 (2010)

18. B. Sasikumar, S. Syamkumar, R. Remya, T. John Zachariah, Food Biotechnol. 18, 299 (2004)

19. M. S. Iqbal, S. Nadeem, S. Mehboob, A. Ghafoor, M. I. Rajoka, A. S. Qureshi, B. Niaz, Turkish J. Agric. For. 35, 569 (2011)

20. N. Khan, F. H. Wattoo, I. Ahmad, I. Muhammad, S. G. Afridi, M. H. S. Wattoo, M. K. S. Safi, Asian J. Biol. Sci. 10, 56 (2017)

21. M. Kay, Cell. Mol. Biol. 51, 117 (2005)

22. M. G. Neghab, B. Panahi, Biotechnologia 98, 97 (2017)

23. S. P. Sudhir, A. Kumarappan, J. Malakar, H. N. Verma, Am. J. Life Sci. 4, 175 (2016)

24. S. E. Emran, Int. J. Pure Appl. Biosci. 5, 787 (2017)

25. S. P. Sudhir, A. Kumarappan, L. K. Vyas, D. Shrivastava, P. Deshmukh, H. N. Verma, Am. J. Life Sci. 4, 118 (2016)

26. S. Pendkar, S. Hegde, S. Nayak, H. Hegde, S. Kholkute, S. Roy, Planta Medica Int. Open. 3, e43 (2016)

27. A. A. Rather, K. Jain, UK J. Pharm. Biosci. 5, 35 (2017) 